\title{
Certification for Green Project Managers (GPM) in the Malaysian Construction Industry: Analysis of Success Factors
}

\author{
Nur Halimah Mohd Saiful Rahim, ${ }^{1, *}$, Zulhabri Ismail ${ }^{1}$, and Rumaizah Mohd Nordin ${ }^{1}$ \\ ${ }^{1}$ Faculty of Architecture, Planning and Surveying, Universiti Teknologi MARA (UiTM), 40450, Shah Alam, Selangor, Malaysia
}

\begin{abstract}
Since the 19th century, the sustainability concept has grown rapidly especially in terms of recognition and the issues of achieving it have been addressed by the construction players. The Construction Industry Transformation Plan (CITP) aims by the year 2020 to develop the Malaysian construction industry into an environmentally sustainable construction industry to a point that it can eventually be rolled out as a model to the emerging world. In order to achieve it, the Project Manager's involvement is important when confronting sustainable issues. Therefore, Malaysia has launched its first National Green Project Managers (GPM) Awards in 2015. Although it has been two years, the promotion of certification of GPM is still lacking. Hence, the aim of this paper is to determine the success factors of promoting certified GPM in the Malaysian construction industry. Using a questionnaire survey of 30 respondents, comprising of Project Directors, General Managers and Project Managers, this research focuses on three (3) objectives which are to : (a) explore the need of certified GPM; (b) identify the limitations of promoting certified GPM; (c) establish the success factors of promoting certified GPM in Malaysian construction projects. From the analysis using SPSS, this research discovered the top reason GPMs are needed in the construction industry is because of the responsibilities of GPMs to ensure successful delivery of green development goals. However, there are a number of barriers to promoting certified GPM, which include limited training for Project Managers that touch on sustainability elements. To date, a private sector organization, known as Bridgit, is the sole provider of specific training in GPM in Malaysia. Therefore, training for Project Managers is important to provide them with the necessary skill and knowledge towards becoming certified GPM and turn to achieve as a true success factor. Finally, the outcome of this research will become a baseline to promote certification of GPM in the future.
\end{abstract}

\section{Introduction}

Since the 19th century, the sustainability concept has grown rapidly especially in terms of recognition and the issues of achieving it have been addressed by the construction players to reduce environmental stress [13]. Therefore, the Construction Industry Transformation Plan (CITP) aims by the year 2020 to develop the Malaysian construction industry into an environmentally sustainable construction industry to a point that it can eventually be rolled out as a model to the emerging world [4]. In order to achieve it, the Project Manager's involvement is important when confronting sustainable issues. Therefore, Malaysia has launched its first National Green Project Managers (GPM) Awards in 2015. Although it has been two years, the promotion of certification of GPM is still lacking.

\section{Literature review}

Previous studies have claimed that sustainability issues play a significant role in attaining green project management [5-9]. Nevertheless, considering the construction industry in developing countries like Malaysia, strength in terms of sustainability has not yet reached an adequate level as challenges of sustainable construction and development are not really being dealt with [10]. This was concluded by $[11,12]$ that Project Managers (PM) are important "change agents" in organizations that have a strong influence on the sustainability of organizations to reduce the impact on the environment. Furthermore, the relationship of PM competencies towards successful projects have been mention over the past couple of decades by many types of research [13-19].

Apart from this statement, Malaysia has launched the first National Green Project Managers (GPM) Awards in 2015. Although it has been two years, the promotion of certification of GPM is still lacking. Therefore, this research paper has begun to explore the issues of limitation in green project management practices in Malaysia through the participation in green building development. Based on Table 1, it is recorded that the total number of construction projects from the year 2013 to 2015 are 5987, 7939 and 6885 respectively. Nevertheless, the construction projects registered with Green Building Index (GBI) is relatively small if

\footnotetext{
* Corresponding author: halimahsaifulrahim@gmail.com
} 
compared with the overall construction projects executed in Malaysia.

Table 1. Comparison analysis of total construction projects [20-21].

\begin{tabular}{|c|c|c|}
\hline Year & $\begin{array}{c}\text { Total Construction } \\
\text { projects }\end{array}$ & $\begin{array}{c}\text { Total registered } \\
\text { projects }\end{array}$ \\
\hline 2013 & 5985 & 476 \\
\hline 2014 & 7939 & 595 \\
\hline 2015 & 6885 & 664 \\
\hline
\end{tabular}

On the other hand, GBI has targeted to achieve 200M sq $\mathrm{ft}$ of green building in Malaysia by the end of 2016. So far, this has not been met even until 2017. There are only $195,777,797$ sqft certified green buildings, short by $4.2 \mathrm{M} \mathrm{sq} \mathrm{ft} \mathrm{[15].} \mathrm{This} \mathrm{indicates} \mathrm{that} \mathrm{the} \mathrm{GPM} \mathrm{has} \mathrm{to} \mathrm{play}$ a bigger role to achieve this target. Although green buildings serve a broad range of benefits for the society and environment, [22] argues that green projects require more cost compared to conventional projects due to the uncertainty and high cost of green equipment and materials, leading to some challenges in green project management. In addition, characteristics of the green building that is significant with the environment requirement as well as the complexity of delivering of these projects are reasons for the rising costs in realization of green building [23]. This directly affects the PM if the cost of green construction is high as they are responsible for managing and delivering their projects within an allocated budget [11].

Despite the cost and profit being main elements defining the success of projects, few studies conducted had clarified that there is a well-known gap of green development as there are many PMs who refuse to accept the changing trend towards going green [24]. The expected perceptions of responsibilities of PM in managing and tight budgets with small profit margins on green project is one of the heightened perceptions of risks associated with going green [7]. Hence, the GPM is essential in improving project performance especially in terms of cost that are embedded in every project organization in particular that have an impact on green building projects [23].

\section{Research methodology}

The aim of the research is to establish the success factors in the certification of GPM. Therefore, and a thorough literature search was completed and a quantitative approach for data collection adopted. In this case, the data was collected through a selfadministered questionnaire. Thirty (30) respondents from various backgrounds either Project Directors, General
Managers or Project Managers were identified either through face to face or telephone interviews [25]. The respondents were asked to rate the extent to which each of the challenges affected them using a 5-point Likert scale ( $1=$ strongly disagree; $5=$ strongly agree). Since questionnaires mostly come with standardized questions, it makes the process much simpler and more efficient.

Snowball sampling was adopted where the potential respondent was hard to find and the sample cannot be calculated. This is a sufficient number to analyse the data as the snowball technique is able to verify the respondents' accounts, when possible, through third parties where data sources were triangulated [26-27]. In many cases, third-party verification was accomplished through a person (known as a locator) by contacting respondents personally known by him or her to fit the research criteria. This is the person who literally would start a snowball [28].

\section{Results and Discussion}

For the purpose of this research, the researcher used descriptive analysis throughout data analysis using SPSS statistics. The data findings were presented in four (4) sections as such, each section would address the respective research intentions as tabulated in Table 2. Then, results were summarized as shown in Table 3 that categorized into their mean score and ranks across the data.

Table 2. Details / Area of Research.

\begin{tabular}{|c|c|c|}
\hline Section & Details/ Area of research & Objective \\
\hline A & $\begin{array}{c}\text { Respondent's Demographic } \\
\text { Background }\end{array}$ & $\begin{array}{c}\text { General } \\
\text { information }\end{array}$ \\
\hline B & $\begin{array}{c}\text { The need of certified Green } \\
\text { Project Manager (GPM) }\end{array}$ & 1 \\
\hline C & $\begin{array}{c}\text { Limitations of promoting } \\
\text { certified Green Project } \\
\text { Manager (GPM) }\end{array}$ & 2 \\
\hline D & $\begin{array}{c}\text { Success factors of promoting } \\
\text { certified Green Project } \\
\text { Manager (GPM) }\end{array}$ & \\
\hline
\end{tabular}

\subsection{Respondent's Demographic Background}

This section was designed to determine the sustainability of the respondents and to ensure the validity of the primary data in view of the objectives of this research study. It is important to highlight respondents' particular details, as it gives the overview of the respondents' background and increases the reliability and consistency of the response throughout the research. 
Table 3. Summary result and discussion categorized into mean and score.

\begin{tabular}{|c|c|c|c|c|}
\hline Codes & Variables & Mean & Overall & Rank \\
\hline \multicolumn{5}{|c|}{ The need for certified GPM in Malaysia construction industry (Objective 1) } \\
\hline \multicolumn{5}{|c|}{ N1. Responsible to avoid cost constraint } \\
\hline N1.i & GPM is responsible for managing and delivering projects within an allocated budget. & 4.43 & \multirow{4}{*}{4.07} & \multirow{4}{*}{2} \\
\hline N1. ii & GPM is responsible for managing a tighter budget on the green project & 3.60 & & \\
\hline N1.iii & GPM is needed in improving project performance especially in term of cost & 4.23 & & \\
\hline N1. iv & $\begin{array}{l}\text { Appoint a competent PM in managing green is one of the solutions to ensure project } \\
\text { completed within established time and cost }\end{array}$ & 4.00 & & \\
\hline \multicolumn{5}{|c|}{ N2. GPM is important to ensure successful delivery of green development. } \\
\hline N2. i & There is a need for managers to think "go green" in order to deliver green building & 4.13 & \multirow{3}{*}{4.10} & \multirow{3}{*}{1} \\
\hline N2. ii & An experienced GPM is important to ensure successful delivery of green building & 4.00 & & \\
\hline N2.iii & $\begin{array}{l}\text { PM and project team are among the key factors contributing to the success of green } \\
\text { building project implementation }\end{array}$ & 4.17 & & \\
\hline \multicolumn{5}{|c|}{ N3. PM react as catalyst "agent" to achieve goals of green } \\
\hline N3. i & Role of PM needs to be adapted to achieve issue regarding green. & 3.83 & \multirow{4}{*}{3.83} & \multirow{4}{*}{3} \\
\hline N3. ii & PM direct influence ensures project success & 3.80 & & \\
\hline N3.iii & $\begin{array}{l}\text { A competent PM able to reduce carbon emissions together to maintain all benefits of } \\
\text { green building }\end{array}$ & 3.70 & & \\
\hline N3. iv & $\begin{array}{l}\text { PM plays a role to enhance the implementation of technological innovation for the } \\
\text { success of implementation green development. }\end{array}$ & 4.00 & & \\
\hline \multicolumn{5}{|c|}{ The limitation of promoting certified GPM in the Malaysian construction industry (Objective 2) } \\
\hline \multicolumn{5}{|c|}{ L1. Financial barriers } \\
\hline L1. i & $\begin{array}{l}\text { Perception of rising unsubstantiated cost among professional in the construction } \\
\text { industry when dealing with sustainable construction }\end{array}$ & 4.40 & \multirow[t]{2}{*}{4.39} & \multirow[t]{2}{*}{2} \\
\hline L1. ii & Initial extra cost is needed to implement sustainable construction. & 4.37 & & \\
\hline \multicolumn{5}{|c|}{ L2. Market Demand } \\
\hline L2. i & Lack of demand for certified green project manager. & 4.00 & \multirow{2}{*}{4.09} & \multirow{2}{*}{3} \\
\hline L2. ii & Construction is a profit-driven industry & 4.17 & & \\
\hline \multicolumn{5}{|c|}{ L3. Limited training for PM that considers sustainability elements. } \\
\hline L3. i & PM trained in sustainability is a necessary element to achieve sustainably & 4.17 & \multirow{3}{*}{4.41} & \multirow{3}{*}{1} \\
\hline L3. ii & $\begin{array}{l}\text { Establishing training module for each competency will improve their competency in } \\
\text { managing green construction projects }\end{array}$ & 4.50 & & \\
\hline L3.iii & $\begin{array}{l}\text { Training module also give benefit in increasing the probability of producing a } \\
\text { successful green construction project in the future }\end{array}$ & 4.57 & & \\
\hline & L4. "Going Green" is something new towards participant in the constructio & industr & & \\
\hline L4. i & Unclear on the concept of sustainable construction. & 3.57 & & \\
\hline L4. ii & $\begin{array}{l}\text { Confuse on the terms sustainable construction, sustainable building, green construction } \\
\text { and green building (GB) }\end{array}$ & 3.70 & & \\
\hline L4.iii & Construction player have no clear ideas on how to manage GB projects & 3.57 & 3.69 & 4 \\
\hline L4. iv & $\begin{array}{l}\text { Project management guidelines, standards and competence requirements for PM tend } \\
\text { to neglect the area of sustainability. }\end{array}$ & 3.93 & & \\
\hline & L5. PM refuses to accept changing to sustainable/ green project manag & nent: & & \\
\hline L5. i & Many PM and project teams are having difficulties in adapting GPM & 3.53 & & \\
\hline L5. ii & PM more expect to use conventional practices that have been used for decades & 3.50 & & \\
\hline L5.iii & There is insufficient proof of the advantages of sustainable construction & 3.40 & 3.49 & 5 \\
\hline L5. iv & Clients are not aware of sustainable construction. & 3.53 & & \\
\hline & The success of certified Green Project Manager (GPM) In Malaysia construction ind & istry $(0$ & tive 3). & \\
\hline & S1. Skills and knowledge & & & \\
\hline S1.i & Technical knowledge regarding green technology & 4.30 & & \\
\hline S1. ii & Additional knowledge of green certificates requirement & 4.23 & 4.31 & 2 \\
\hline S1.iii & Skill and knowledge as the competencies for GPM & 4.40 & & \\
\hline & S2. Training module & & & \\
\hline S2. i & Training as a foundation for on-site construction personnel. & 4.47 & & \\
\hline S2. ii & Training module help PM competency in managing green construction projects & 4.33 & 4.43 & 1 \\
\hline S2.iii & Training allows strengthening the skill that PM needs to improve & 4.50 & & \\
\hline & S3 Ethical aspect & & & \\
\hline S3. i & $\begin{array}{l}\text { Honesty responsibility, respect and fairness are the values that drive ethical conduct for } \\
\text { the green project management profession }\end{array}$ & 4.53 & & \\
\hline S3. ii & $\begin{array}{l}\text { Ethical aspect already accepted as a fundamental skill in project administrator training } \\
\text { and accreditation, especially regarding green. }\end{array}$ & 4.10 & 4.31 & 2 \\
\hline S3.iii & Without ethical competence, GPM will not be able to achieve professionalism & 4.30 & & \\
\hline & $\begin{array}{ll}\text { S4. Competencies } \\
\end{array}$ & & & \\
\hline S4. i & GPM is lacking competencies to consider the sustainability aspects of their projects. & 4.10 & & \\
\hline S4. ii & Competencies of sustainable poorly stated in the standard of project management & 4.23 & & \\
\hline S4.iii & $\begin{array}{l}\text { A competency is important to develop adequate consulting skills, build expertise in the } \\
\text { aspects that determine the sustainability impact of the project and complexity around } \\
\text { the projects. }\end{array}$ & 4.43 & 4.25 & 3 \\
\hline
\end{tabular}


In summary, the respondent's years of experiences are 05 years $(26.7 \%), 5-10$ years $(26.7 \%), 10-15$ years $(20 \%)$, and above 15 years $(26.7 \%)$. It is present that the respondent's years of experience is equally distributed between the different group of years.

Generally, $90 \%$ of the respondents who participate in this survey are those directly involved in managing projects from top management and had extensive experience in the construction industry. Only $10 \%$ of the respondents comprised of project engineers and QA/QC staff. Professional respondents are typically identified as having a high level of integrity that is important as the most essential leadership trait from top management. Therefore, data collected from these people should be trustworthy and representative.

\subsection{Research finding and analysis for the need of certified Green Project Manager (Objective 1)}

Most of the respondents agree that GPM is important to ensure successful delivery of green development, with the highest overall mean of 4.10. It is a norm that a Project Manager is appointed by "project owner" or "company owner" and would carry out the responsibilities and work as per the employer's order to ensure the project is done within the allocated time, cost and quality. However, the issue of "green" is taking a back seat as the PM's avoidance to think "green" in the project unless it has been explicitly stated in the contract requirement or is an environmental requirement under the law [29-30]. Example of PM to think "green" in the construction project includes anticipating how to reduce noise and air pollution. Therefore, it is proof that the GPM plays a big role in delivering successful green development goals.

\subsection{Research finding and analysis for the limitation of promoting certified Green Project Manager (GPM) (Objective 2).}

Limited training for PM that considers sustainability elements, is the most agreed to by the respondents and have the highest overall mean of 4.41. Back to the literature review, previous researchers have emphasized that training is important to attain a green and sustainable status for projects in the construction industry [31- 35]. However, the survey results on participants, respondents or employees in training and seminars etc focusing on green management, it found that $66.7 \%$ of respondents do not attend any seminars or training on green management and only $23.33 \%$ of respondents have participated in it. This gap proves that Bridgit being the sole training centre that promotes a specific training on GPM in Malaysia. Therefore, this shows that limited training for PM that considers sustainability elements is one of the main barriers of promoting certified GPM.

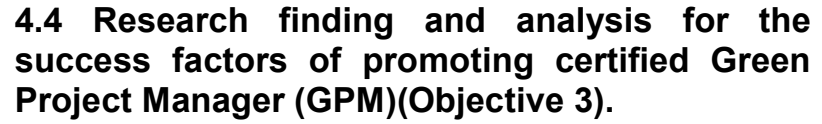

4.4 Research finding and analysis for the success factors of promoting certified Green Project Manager (GPM)(Objective 3).

The first ranking the respondents choose is training modules that strengthen the skill among PM (4.50 mean). This is perhaps due to the need of a PM to be skilled in identifying green innovation as well as enhance the skill that the PM needs to improve as mention by [15]. Therefore, training sessions on green buildings seem like a requirement of one component for on-site construction personnel along as a foundation towards promoting environmental sustainability [31].

Moreover, relating back to the limitation as mentioned in objective 2 that indicates 4.57 mean of the respondents strongly agree that the training module is significant and beneficial in increasing the probability of producing a successful green construction in the future. Hence, training for PM is important to provide skill and knowledge in order for them to become certified GPM and make a true success factor.

\section{Conclusion}

Generally, a PM is responsible to handle the project within stipulated time, cost and quality. However, since issues of global warming and the construction industry contributing to large number of carbon dioxide released into the atmosphere, there are a lot of initiatives being taken to reduce the impact on the environment. Apart from that, this issue is alarming in the construction industry and therefore GPM is quite in need in order to solve this problem. Thus, this research briefly presents that GPM is needed to avoid cost constraint in the management of green building and important to successfully deliver green development as a catalyst/agent to achieve goals of green to minimize the impact on the environment.

However, even after two years of launching GPM in Malaysia, there is no proof of any improvement of this profession. Therefore, to promote GPM in Malaysia, more training on the sustainable element and 'going green' for PM is indeed important. PM must be educated and train to downplay their perception of the rise in unsubstantiated cost among professional in the construction industry. Hopefully, the PM of the future would be able to accept the changes required on sustainable/green project management. Hence, the outcome of this research will become a baseline to promote certification of GPM in the future.

\section{References}

1. Bragança, L., Mateus, R., \& Koukkari , H. (2010). Building Sustainability Assessment. Sustainability .

2. Moradi , A. M., Hosseini, B., \& Yazdani, H. (2018). Principles of assessment and improvement of construction systems environmental sustainability in Iran (By Lifecycle Numerical Parametric Measurement Approach). International Journal of Architectural Engineering \& Urban Planning.

3. Neyestani, B. (2017). A Review on Sustainable Building (Green Building). Department of Civil Engineering, De La Salle University, Manila. 
4. Environmental Sustainabilty. (2017). Retrieved 10 10, 2017, from CITP: http://www.citp.my/strategicthrusts/environmentalsustainability/

5. Aghili, N., Mohammed, A. H., \& Ting, L. S. (2016). Key Practice for Green Building Management in Malaysia. MATEC Web of Conferences, 1-5.

6. Okland, A. (2015). Gap Analysis for Incorporating Sustainability in Project Management. Procedia Computer Science, 103-109.

7. Robichaud, L. B., \& Anantatmula, V. S. (2011). Greening Project Managment Practices for Sustainable Construction. Journal of management in engineering, 48-57

8. Sadaba, S. M., Jaen, L. F., \& Ezcurdia, A. P. (2015). Using Project Management as a Way to Sustainability. From a Comprehensive Review to a Framework Definition. Journal of Cleaner Production, 1-16

9. Silvius, G. A., \& Schipper, R. P. (2014). Sustainability in Project Management Competencies: Analyzing the Competence Gap of Project Managers. Journal of Human Resource and Sustainability Studies, 40-58.

10. Tabassi, A. A., \& Argyropoulou, M. (2016). Leadership Behavior of Project Managers in Sustainable Construction Projects. Procedia Computer Science, 724-730.

11. Hwang, B. G., \& Ng, W. J. (2013). Project Management Knowledge and Skills for Green Construction: Overcoming Challenges. International Journal of Project Management, 272284

12. Lokman, M. A., \& Abdullah, M. N. (2017). Exploring Competencies for Green Building Project Manager. International Journal of Real Estate Studies.

13. Geoghegan, L., \& Dulewicz, V. (2008). Do Project Managers' Leadership Competencies Contribute to Project Success? Project Management Journal.

14. Kissi, J., \& Dainty, A. (2013). Examining the Role of Transformational Leadership of Portfolio Managers in Project Performance. International Journal of Project Management.

15. Mir, F. A., \& Pinnington, A. H. (2014). Exploring the Value of Project Management: Linking Project Management Performance and Project Success. International Journal of Project Management, 202207.

16. Muller, R., \& Turner, R. (2010). Leadership Competency Profiles of Successful Project Managers. International Journal of Project Management, 437-448.

17. Nauman, S., \& Khan, M. A. (2010). Patterns of Empowerment and Leadership Style in Project Environment. International Journal of Project Management, 635-649.

18. Walker, B. L., \& Walker, D. (2011). Authentic Leadership for 21st-century project delivery. International Journal of Project Management, 383395.
19. Yang, L. R., Huang, C. F., \& Wu, S. K. (2011). The Association Among Project Manager's Leadership Style, Teamwork and Project Success. International Journal of Project Management, 258-267.

20. CIDB. (2012). Retrieved May 25, 2016, from CIDB:http://www.cidb.gov.my/cidbv4/index.php?la $\mathrm{ng}=\mathrm{en}$

21. Green Building Index. (2016). Retrieved 11 2, 2017, from Green Building Index: http://new.greenbuildingindex.org/newsFolder/news 2016

22. Hwang, B. G., \& Ng, W. J. (2013). Project Management Knowledge and Skills for Green Construction: Overcoming Challenges. International Journal of Project Management, 272284.

23. Li, Y. Y., Chen, P. H., \& Chew, D. A. (2011). Critical Project Management Factors of AEC Firms for Delivering Green Building Projects in Singapore. Journal of Construction Engineering And Management, 1153-1163

24. Lokman, M. A., \& Abdullah, M. N. (2017). Exploring Competencies For Green Building Project Manager. International Journal of Real Estate Studies.

25. Marshall, B., \& Cardon, P. (2013). Does Sample Size Matter In Qualitative Research ?: A Review of Qualitative Interview in research. Journal of Computer of Information System.

26. Denzin, N. K. (1970). The Research Act: a Theoretical Introduction to Sociological Methods. California: Aldine Pub. Co.

27. Webb, E. J., Campbell, D. T., \& Schwartz, R. D. (1966). Unobtrusive Measures: Nonreactive Research in the Social Sciences. England: Oxford.

28. Biernacki, P., \& Waldorf, D. (1981). Snowball Sampling Problems and Techniques of Chain Referral Sampling. Sociological. Methods \& Research, 141-163.

29. Kubba, S. (2010). Green Construction Project Management and Cost Oversight. United State: Elseveir Inc.

30. Maltzman, R., \& Shirley, D. (2010). Green Project Management. United State: CRC Press.

31. Bourdeau, L. (1999). Sustainable Development and The Future of Construction: a Comparison of Visions from Various Countries. Building Research and Information, 354-366.

32. Plessis, C. D. (2007). A Strategic Framework for Sustainable Construction in Developing Countries. Construction Management and Economics, 67-76.

33. Geoghegan, L., \& Dulewicz, V. (2008). Do Project Managers' Leadership Competencies Contribute to Project Success? Project Management Journal.

34. Kibwami, N., \& Tutesigensi, A. (2016). Enhancing Sustainable Construction in The Building Sector in Uganda. Habitat International, 64-73.

35. Martens, L. M., \& Carvalho, M. M. (2016). Key Factors of Sustainability in Project Management Context: A Survey Exploring the Project Managers's 
Perspective. International Journal of Project Management, 1084-1102 